Nutrigenetics

Nutrigenomics

\title{
Impact of Nutritional Epigenomics on Disease Risk and Prevention
}

Guest Editor

Thomas P. Ong, São Paulo

6 figures, 2012 
S. Karger

Medical and Scientific Publishers Basel · Freiburg · Paris · London · New York · New Delhi $\cdot$ Bangkok . Beijing · Tokyo $\cdot$ Kuala Lumpur Singapore $\cdot$ Sydney

www.karger.com
The statements, opinions and data contained in this publication are solely those of the individua authors and contributors and not of the publisher and the editor(s). The appearance of advertisements in the journal is not a warranty, endorsement, or approval of the products or service advertised or of their effectiveness, quality safety. The publisher and the editor(s) disclaim responsibility for any injury to persons or property resulting from any ideas, methods, instructions or products referred to in the content or advertisements.

Drug Dosage

The authors and the publisher have exerted every effort to ensure that drug selection and dosage se forth in this text are in accord with current recommendations and practice at the time of publication. However, in view of ongoing research, changes in government regulations, and the constant flow of information relating to drug therapy and drug reactions, the reader is urged to check the package insert for each drug for any chang in indications and dosage and for added warnings and precautions. This is particularly important when the recommended agent is a new and/ or infrequently employed drug.
All rights reserved.

No part of this publication may be translated into other languages, reproduced or utilized in any form or by any means, electronic or mechanical including photocopying, recording, microcopying, or by any information storage and retrieval system, without permission in writing from the publisher or, in the case of photocopying, direct payment of a specified fee to the Copyright Clearance Center (see 'General Information’).

(C) Copyright 2012 by S. Karger AG,

P.O. Box, CH-4009 Basel (Switzerland)

Printed in Switzerland

on acid-free and non-aging paper (ISO 9706) by

Reinhardt Druck, Basel

ISBN 978-3-8055-9950-4

e-ISBN 978-3-8055-9951-1 
Vol. 4, No. 5, 2011

Journal of

Nutrigenetics

Nutrigenomics

\section{Contents}

Introduction

245 Impact of Nutritional Epigenomics on Disease Risk and Prevention: Introduction

Ong, T.P. (São Paulo); Pérusse, L. (Québec, Qué.)

Minireviews

248 The Effect of Nutrition during Early Life on the Epigenetic Regulation of Transcription and Implications for Human Diseases

Lillycrop, K.A.; Burdge, G.C. (Southampton)

261 Epigenetics: A Tool to Understand Diet-Related Cardiovascular Risk?

Zaina, S. (León); Lund, G. (Irapuato)

275 Targeting the Epigenome with Bioactive Food Components for Cancer Prevention

Ong, T.P.; Moreno, F.S. (São Paulo); Ross, S.A. (Bethesda, Md.)

293 Polymorphisms in 1-Carbon Metabolism, Epigenetics and Folate-Related Pathologies

Stover, P.J. (Ithaca, N.Y.)

307 ISNN Society News

308 ISNN Membership Application Form

() 2012 S. Karger AG, Basel 